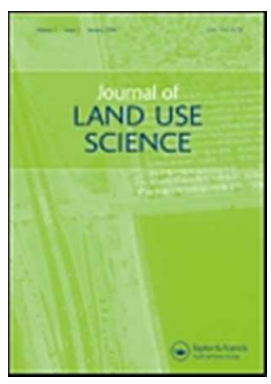

\title{
Peri-urban land grabbing? Dilemmas of formalising tenure and land acquisitions around the cities of Bamako and Ségou, Mali
}

\begin{tabular}{|r|l|}
\hline Journal: & Journal of Land Use Science \\
\hline Manuscript ID & TLUS-2018-0068.R1 \\
\hline Manuscript Type: & Short Communications \\
\hline Keywords: & Urbanization, Africa, Land tenure, Mali, Peri-urban \\
\hline \multicolumn{2}{|l}{} \\
\hline
\end{tabular}

SCHOLARONE $^{\text {m }}$

Manuscripts 


\section{Peri-urban land grabbing? Dilemmas of formalising tenure and land acquisitions around the cities of Bamako and Ségou, Mali}

\section{Introduction}

This brief note identifies the consequences of land acquisitions in peri-urban spaces around the cities of Bamako and Ségou, Mali. It contributes to important debates between those forcefully promoting, and others more critical of, formal land tenure as a pathway for development (Lund 2009; Peters 2009; Vermeulen and Cotula 2010). These longstanding questions are particularly relevant to peri-urban areas now faced with an ever-increasing rural-urban migrant population settling in precarious conditions of insecurity property rights. West Africa has a long history of urbanisation, in some cases accompanied by highly productive and intensified land use (Cour 2001). Yet peri-urban zones, while at the heart of intense conflicts over land values and claims (Aguilar et al. 2003; Hoggart 2012), are less highlighted in scientific assessments of land use (see Müller and Munroe 2014) and in policy circles (Cotula et al. 2004). What are the current challenges of applying more formal land tenure models to peri-urban areas given their populations are increasingly precarious, and environments where historically high elite capture of rents and other economic benefits? What can the cases in Mali described below tell us more broadly about peri-urban and/or African urbanization and land use?

Conflicts in peri-urban areas arise mainly between those who have access to political power and knowledge about land administration procedures, and those who do not (Bertrand 2016, Djiré 2007, Durand-Lasserve 2014). Accessing the formal land titling system offers rewards to those who understand and can afford it. For the rest, not only are formal procedures complex and too costly, but they also face risk of eviction from land titled by others (Place 2009). In many cities, land tenure practice involves a mix of opportunistic behaviour and formal procedures, often negotiated through elite brokers who have knowledge of the existing land registration system and connections to those able to secure formal tenure rights (Djiré 2007). Purchase of an urban plot is a valuable asset for a wide range of stakeholders, from rural and urban backgrounds, offering one route out of rural poverty, if they can make the process work in their favour.

Urban populations throughout West Africa are expected to triple by 2050, which poses major problems for ensuring adequate public infrastructure and services in newly settled peri-urban zones. Equally, attention is needed to establish some form of local tax, based on land values, which can provide a source of revenue to local government, which rises in-line with the growth, and economic success of the town or city in question. Given the high levels of poverty amongst urban incomers, some means provide secure rights at reasonable cost so to decrease elites acquiring and developing urban land.

The Malian cadastre was created in 2014, with the aim of providing a comprehensive register of urban land in the first instance. However, so far, the inventory has been pieced together from fragmented records, rather than taking a systematic approach, and the information is treated as confidential. Consequently, it is not possible for people to check who is claiming rights over a given plot. At the same time, when people seek title, notice of this request is rarely posted in a location close to the land in question, where public scrutiny would be possible. As a result, the first local people may know of such a title acquisition is when surveyors arrive to install boundary posts. 
However, formal land titling programmes continue to be a central development strategy promoted by development economists and land policy specialists in Mali and elsewhere (FAO 2017), even as their appropriateness is questioned (Deininger 2003). Peri-urban spaces, arguably one of the fastest growing geographical locations in the global south, raise additional concerns around the opacity of processes by which customary farmland is transformed into housing plots, and the large increase in value which accompanies this transfer. It is, therefore, vitally important to question whether formal property rights within peri-urban spaces are a viable option for securing rights for those most marginal and/or recently disposed of their rural landholdings. Are there alternative formalisation mechanisms, which avoid the hazards associated with formal titling, and that address the precarious tenure conditions in peri-urban zones? Or do asymmetries in wealth and knowledge always work against the interests of poor people?

\section{Peri-urban growth in Mali}

In Mali, the peri-urban space increasingly harbours economic migrants establishing a toehold in the city while retaining familial rights to their customary farmland or pastoral livelihoods. Being a successful farmer demands access to land, labour and capital equipment, such as oxen plough-teams, and donkey carts. The rural poor may be forced to abandon farming or find it too onerous, and seek their fortune in town, particularly with the recent rise in jihadistled conflicts in central and northern regions (see below). ${ }^{1}$ As recent migrant Ndje says, “...although I never really chose to come and settle in Bamako, now I am here, it's too difficult to go back to the village and farm, I don't have the wealth to buy the farm equipment I would need, and my children are Bamakois born and bred." In the face of rapid urban growth (Bamako is currently growing at $6 \%$ a year), central and municipal governments have limited capacity to manage and plan the peri-urban space. However, because land titles are a significant source of income for government, and for officials controlling the procedure, the Ministry of Lands ${ }^{3}$ is under heavy pressure to retain this high-cost procedure, rather than certificates of occupation, which are more transparent and accessible. At the same time, the continual conversion of farmland to building plots creates an uplift in land values per hectare, which can bring a hundred-fold return on the original price, creating strong incentives for responsible landholders to agree changes in use, which generates such substantial returns.

The links between land tenure, economic transformations and pathways out of poverty are strong in Mali. Economic growth has averaged 5\% a year for the last decade, but its benefits have been highly skewed, sustaining a small but significant economic and political class. Business elites, better-off rural dwellers and middle-class professionals all acquire land, as prices rise. Large numbers of poor people depend on the informal economy, in which multiple and diverse micro-enterprises seek a niche in the peri-urban space, despite their vulnerability to eviction. Municipal councils are always short of the revenue needed to fund basic services - health, education, water - and a simple land tax on the value of a given plot would be of considerable long-term benefit, and more democratic than present arrangements. However, without an effective register of urban land plots, it is difficult to establish such a mechanism. It would also require that local governments be allowed to keep much of the revenue raised instead of this being sent directly to the ministry of finance. Currently, therefore, the large uplift in urban and peri-urban land values is captured entirely by private actors, rather than contributing to the public good.

\footnotetext{
${ }^{1}$ See Special report New York Times: Heat, Hunger and War Force Africans Onto a 'Road on Fire' http://www.nytimes.com/interactive/2016/12/15/world/africa/agadez-climate-change.html?_r=1 (16/12/16)

${ }^{2}$ Interview Bamako, March 2017.

${ }^{3}$ Ministère des Domaines de 1'Etat, Affaires Foncières et Habitat.
} 
Mali as a whole faces complex and deep-rooted governance, development, poverty and security challenges. Mali is 175 th out of 188 countries on the UNDP's Human Development Index, with 78 percent of the population living on under US\$2/day. An ongoing civil war in the north of the country, and the rise of jihadist movements amongst Fulani herding groups in the centre, trace some of their origins to increased land pressures and scarcity of grazing. The Fulani also feel they have suffered political and economic neglect by central government, in comparison to the rebels in the north, and settled farming peoples in the south of the country. In the irrigable lands close to Ségou along the Niger River and Canal du Sahel, controlled by the state-owned Office du Niger, large-scale land acquisitions for rice, sugar and oil seed have evicted both farmers and herders, increasing migratory drift to cities and placing additional pressures on peri-urban land and livelihoods for recent and longstanding residents.

Given rising land prices provoked by increased demand and proximity to jobs and markets, land in the peri-urban zone is an important economic resource for those with some money to invest, and can provide new income opportunities (Mitlin and Satterthwaite 2013). As a recent migrant to Ségou, Ganiba says, "I've been lucky enough to get a plot of building land on the edge of Ségou, in exchange for important work I did for a powerful man. I am now saving up to construct a house on the plot, which will provide lodging for my family from the village when they visit the city. I've heard the value of the plot has already risen a lot." The economic balance is a fine one: Dunamba, who has been living on the edge of Bamako for 20 years, in a house which does not yet have formal status, says, "every day in the city is hard work, you need cash for everything - rent, food, water, schooling... the only way to keep ahead is to develop a skill. Luckily I drive a van which earns me some money."4

\section{New land laws in Mali}

The government of Mali has been discussing reforms to land tenure for more than a decade, but with limited practical impact. Land tenure regulations have evolved from Independence in 1960, when the socialist government of Modibo Keita maintained the central government's ownership of all land. This policy, inherited from the colonial administration, essentially ignored customary claims to land and natural resources, such as pastures and woodland. The Code Domanial et Foncier de 1986 introduced the recognition of customary rights, and compensation procedures in the event of land being expropriated by government. In practice, examples of paid compensation have been rare. Since 2006, the agricultural land law process has been underway, which led finally to adoption of the new Agricultural Land Tenure Law, which received parliamentary approval, and was promulgated by government in April $2017 .^{5}$ The government also initiated a land policy review in 2017 , to clarify how conflicting claims to rural and urban land might be resolved. The government is considering limits to eminent domain, the status of customary rights, and the appropriateness of land titling versus other cheaper, simpler forms of rights registration, such as certificates that attest to land use and occupation. Nevertheless, given the scale of gains generated from land sales, many peri-urban zones have conflicts between state and customary claims and procedures, particularly where new infrastructure is planned that will radically transform transport links (Bah et al., 2003; Bertrand 2017; Djiré 2007). One such example concerns the planned bridge over the river Niger at Ségou, which would open up a large region on the north bank of the river that has suffered poor transport access to date.

\footnotetext{
${ }^{4}$ Interview Bamako October 2016.

${ }^{5}$ There is no explicit connection between the 2014 Cadastral and the Land Tenure Law. If anything, it represents the usual muddle of different policies and institutions led by different donors and ministries. The cadastre has been operating mainly in Bamako, by the German development agency.
} 
In 2009, the city of Bamako had an estimated 1.8 million people, and was the fastest growing city in Africa. Today, its population is likely to exceed 2.5 million, though the data are patchy given the extensive informal settlements in the peri-urban zone, stretching out more than $30 \mathrm{~km}$ from the city centre. Many "rural" communes have been incorporated de facto into the city, though they retain their separate administrative status. The city of Ségou is Mali's third largest, lying $200 \mathrm{~km}$ east of the capital, with an estimated 200,000 people. Located mainly on the southern bank of the river Niger, it is a long-established trading hub between the dry Sahel to the north and the wetter, savannah zone to the south. In both cities, large informal settlements and urban poverty are on the rise, with an increase in peri-urban populations in areas often poorly planned and vulnerable to climate impacts. Examples include flooding of precarious settlements in low-lying areas surrounded by hills, such as the rural commune of Djalakorodji, to the north of Bamako. Large-scale land allocations to domestic and foreign investors include 20,000 hectares given to N-Sukala, a Chinese company, for irrigated sugar cane. This plantation was established on former rain-fed farmland "owned" and cultivated under customary tenure by seven Bambara villages $30 \mathrm{~km}$ northeast of Ségou. There was no compensation paid to the thousands evicted for the loss of their farmland. Many families have headed northwards to borrow farmland in less land-constrained areas, while others have moved to seek work in town (Toulmin 2018).

\section{Political decentralisation and land}

Mali adopted a political decentralisation program in 1999, which led to the establishment of elected local government, but very little real transfer of power or resources. After the 2012 coup d'état, the government has sought to devolve a number of institutions and functions to each of the ten regions of the country, a welcome shift away from the highly concentrated economic and political power held by the capital Bamako, which has received the large majority of benefits from state and donor patronage for many decades. While regionalisation should offer a better opportunity to achieve a more balanced pattern of economic and political development, the key to its success will be adequate fiscal transfers to regions, local government and municipal authorities (Sourisseau et al 2016). For instance, the Ségou Region, which has approximately 2 million people and is growing at more than $3 \%$ per year, provides a living to a mosaic of peoples and production systems - pastoral nomads, irrigated rice and sugar, dryland millet, maize, sesame and cotton, and fishing communities. However, with land becoming increasingly scarce and valuable, relations between these different groups have shifted from one of complementarity towards one of increasing tension and conflict.

The peri-urban zone absorbs some of the effects of regional conflicts. As well as increasing land scarcity, conflicts are driven by failures in governance and provision of basic services, particularly in rural areas, and the over-bearing power of state officials, judicial and parastatal agencies (e.g. those responsible for land administration, and the Office du Niger irrigated zone). Army and security services wield great power, and people of all groups try to avoid being stopped and arrested. Recent events suggest that young Fulani men are particularly targeted by the security services and assumed to be jihadist, regardless of the reality. Power and power relations are very clearly understood in Bambara society; those with power are described as fama, and those without fantan. Other power asymmetries affect who can claim rights under either customary or modern systems of governance --literate vs poorly literate, newcomers vs first settlers, herders vs farmers, men vs women, old vs young. Of course, various collective organisations exist to rectify inequalities in access - civil associations, farmer unions, lobby groups, and local radio provide some countervailing power. Yet, many 


\section{References}

Aguilar, A. G., Ward, P. M., \& Smith Sr, C. B. (2003). Globalization, regional development, and mega-city expansion in Latin America: Analyzing Mexico City's peri-urban hinterland. Cities, 20, 3-21.

Bah, M., et al. (2003) Changing rural-urban linkages in Mali, Nigeria and Tanzania, Environment and Urbanization, 15(1): 13-23.

Bazin, F. et la (2017). Irrigation, food security and poverty - Lessons from three large dams in West Africa. www.gwiwestafrica.org

Bertrand, M. et al (2017) Land policy and Urban Development in Mali. Coping with the data quality challenge. Paper prepared for the World Bank Annual Land Conference March.

Bertrand, M. (2017) Challenges for new research on "Mobilities" in three West African capitals. Revue Tiers Monde, June, no. 226.

Cour, J. M. (2001). The Sahel in West Africa: countries in transition to a full market economy. Global environmental change, 11(1): 31-47.

Deininger, K (2003) Land policies for growth and poverty reduction. World Bank, Washington DC.

Djiré, M. (2007). Land registration in Mali, no land ownership for farmers? Observations from Peri-urban Bamako. Drylands Programme Issue Paper no. 144. London, IIED. 
Durand-Lasserve, A et al (2015) Land delivery systems in West African Cities. The example of Bamako, Mali. Washington, World Bank.

Cotula, L., Toulmin, C., \& Hesse, C. (2004). Land tenure and administration in Africa: lessons of experience and emerging issues. London: International Institute for Environment and Development.

FAO (2017). Land tenure journal http://www.fao.org/3/a-i3048t.pdf

Farvacque-Vitkovic, C. et al. (2007). Development of the Cities of Mali - Challenges and Priorities. The World Bank, Africa Region Working Paper Series Number 104a.

GRAD The case of Bamako and its peri-urban settlements, Mali Briefing Paper Series on Rural-Urban Interactions and Livelihood Strategies, Briefing Paper 4 http://pubs.iied.org/pdfs/10503IIED.pdf

Hoggart, K. (2012). The City's Hinterland: Dynamism and divergence in Europe's PeriUrban Territories. Hants: Ashgate.

Lund, C. (2000). African land tenure: Questioning basic assumptions. International Institute for Environment and Development.

Mitlin, D. and D. Satterthwaite (2013). Urban poverty in the global south: scale and nature. Place?, Routledge.

Müller, D.and and Munroe, D. K. (2014). Current and future challenges in land-use science.

New York Times. Special Report: Heat, Hunger and War Force Africans on to a 'Road on Fire'http://www.nytimes.com/interactive/2016/12/15/world/africa/agadez-climatechange.html? $\mathrm{r}=1(16 / 12 / 16)$

Peters, P. E. (2009). Challenges in land tenure and land reform in Africa: Anthropological contributions. World Development, 37(8), 1317-1325.

Place, F. (2009). Land tenure and agricultural productivity in Africa: a comparative analysis of the economics literature and recent policy strategies and reforms. World Development, 37(8), 1326-1336.

Ribot, J. C. (2004). Waiting for democracy: the politics of choice in natural resource decentralization. World Resources Institute, 2004 ix, 140 p

Sourisseau, J.-M., M. Soumare, J.-F. Belieres, J.-P. Guengant, R. Bourgeois, B. Coulibaly, S. Traore. (2016). Diagnostic territorial de la Region de Segou au Mali. Report, L'agence Francaise De Developpement.

Toulmin, C (2018) From Abundance to Scarcity: Consequences of large scale land acquisitions in Central Mali. Paper prepared for presentation at the "2018 World Bank Conference on Land and Poverty” World Bank - Washington DC, March 19-23, 2018. 
Vermeulen, S., \& Cotula, L. (2010). Over the heads of local people: consultation, consent, and recompense in large-scale land deals for biofuels projects in Africa. The Journal of Peasant Studies, 37(4), 899-916. 